\title{
PERCUTANEOUS PROSTATE CRYOABLATION AS TREATMENT FOR HIGH-RISK PROSTATE CANCER
}

Omar Reda El Hayek, Wladimir Alfer Jr., Ernesto Reggio, Antonio Carlos L. Pompeo, Sami Arap, Miguel Srougi

Hayek ORE, Alfer Jr. W, Reggio E, Pompeo ACL, Arap S, Srougi M. Percutaneous prostate cryoablation as treatment for high-risk prostate cancer. Clinics. 2007;62(2):109-12.

PURPOSE: To evaluate percutaneous cryotherapy as a primary treatment option for high-risk prostate cancer patients.

PATIENTS AND METHODS: From October 2000 to February 2005, 21 high-risk (Gleason e $\bullet$ and/or PSA > 10 and/or stage > T2a) prostate cancer patients underwent 24 percutaneous prostate cryoablation procedures. Patients' median age was 70.9 , and the average pretreatment PSA was $19.5 \mathrm{ng} / \mathrm{dL}$. The follow-up period ranged from 6 to 60 months (median, 41 months).

RESULTS: The PSA failure rate was 39\%, 52.9\%, and $42.8 \%$ at 12, 24, and 60 months of follow-up, respectively. Overall complication rates were low, with $8 \%$ of urinary incontinence and no cases of rectal injury; however, $96 \%$ of erectile dysfunction occurred. The cryoablation procedure failed in 12 patients $(57.2 \%) ; 7$ (58.3\%) of these were local failures (positive prostate biopsies).

CONCLUSION: Percutaneous cryoablation of the prostate is a safe minimally invasive treatment, but it has poor PSA-free survival outcomes in high-risk prostate cancer patients.

KEYWORDS: Cryotherapy. Prostatic neoplasms. Salvage cryotherapy.

\section{INTRODUCTION}

Cryoablation is an alternative treatment modality for prostate cancer that destroys tumoral and prostate gland tissue. It was initially introduced in the 1960 s by Gonder et $\mathrm{al}^{1}$, but it was later abandoned because of the high complication rate due to the inability to control the freezing process, causing rectal injury and urethral obstruction. ${ }^{2}$ Only in the 1990s, with the introduction by Gary Onik of a real-time ultrasound visualization associated with temperature sensors ${ }^{3}$, has cryotherapy become a safer and acceptable option for treatment of prostate cancer patients. The procedure allows better control of the "ice ball," avoiding lesions to the surrounding tissue, urinary sphincter, and rectum wall. Many centers around the world are gaining

Hospital das Clínicas, São Paulo University Medical School - São Paulo/SP, Brazil.

Email: hayek@uol.com.br

Received for publication on December 06, 2006.

Accepted for publication on December 19, 2006. experience in this relatively new procedure, with promising results.

High-risk prostate cancer treatment is still a challenge, since most patients develop early recurrence regardless of the treatment modality. Therefore, new modalities, or even combined treatments, have been tested, in attempts to develop a treatment with better recurrence-free survival.

The purpose of this study was to evaluate the treatment of high-risk prostate cancer with cryoablation.

\section{PATIENTS AND METHODS}

Between October 2000 and February 2005, 24 procedures with 3 reapplications were performed on 21 patients. Patients' ages ranged from 55 to 83 years (average, 70.9), with an average pretreatment PSA of $19.5 \mathrm{ng} / \mathrm{dL}$ (range, 4.1 - $56 \mathrm{ng} / \mathrm{dL}$ ). Gleason scores ranged from 4 to 9 (average, 7), and prostate weight ranged from 15 to 50 grams (average, 26.6 grams). Clinical stage distribution was, 10 patients, T2NxMx and 14 patients, T3NxMx. Designation 
of high-risk prostate cancer was based on Gleason e•8, PSA $>10$. and clinical stage $>$ T2a.

Patients with PSA levels over $30 \mathrm{ng} / \mathrm{dL}$ had previously undergone laparoscopic lymph node dissection and were considered for prostate cryoablation only after the nodes were found negative (4 patients). All patients had negative preoperative bone scans for metastatic disease.

Patients were evaluated regarding voiding symptoms and erectile function, being considered impotent when they were unable to perform sexual intercourse due to weak penile rigidity.

All patients received a rectal enema the night before the procedure. Under spinal anesthesia, patients were placed in a lithotomy position. Cystoscopy was undertaken, and a supra-pubic bladder catheter was placed under direct vision. All procedures were performed according to the modified Onik technique using a CRYOCare unit with argonium and helium gas for the freezing and thawing, respectively, for a total of 2 freezing-thawing cycles. Under transrectal ultrasound guidance, 5 to 7 cryoprobes were introduced into the prostate, and 4 thermoprobes were located bilaterally in the neurovascular bundles, one in the Denonvilliers' fascia and the other at the sphincter.

The freezing process was monitored in real time by transrectal ultrasound and thermo probes for direct visualization of the ice ball and to avoid lesions to adjacent tissues. During the procedure, the urethra was protected with a warming device at $37^{\circ} \mathrm{C}$ degrees that was kept in place until the patients left the operating room. All patients were discharged within 24 hours, with the suprapubic catheter removed after a week.

Follow-up was undertaken at 3, 6, and 12 months and annually thereafter in all cases, with clinical evaluation of urinary outflow, continence (number of pads, and erectile dysfunction, followed by digital rectal examination, urine analysis, and PSA measurements. The follow-up period ranged from 18 to 60 months (median, 41 months). Urinary incontinence was defined as the need for pads.

Patients who did not reach a PSA nadir of $1 \mathrm{ng} / \mathrm{dL}$ or less underwent prostatic biopsy followed by a bone scan to evaluate the possibility of local or distant recurrence. Patients with local recurrence only (PSA > $1 \mathrm{ng} / \mathrm{mL}$, negative bone scan, and positive biopsy), underwent an additional cryoablation procedure (reapplication).

\section{RESULTS}

The PSA failure rate was $39 \%$ and $52.9 \%$, respectively, at 12 and 24 months of follow-up, with an average posttreatment PSA of 8.68 and $12.3 \mathrm{ng} / \mathrm{dL}$, respectively. At the 60-month follow-up, $42.8 \%$ of the patients were free of PSA relapse (Figure 1).

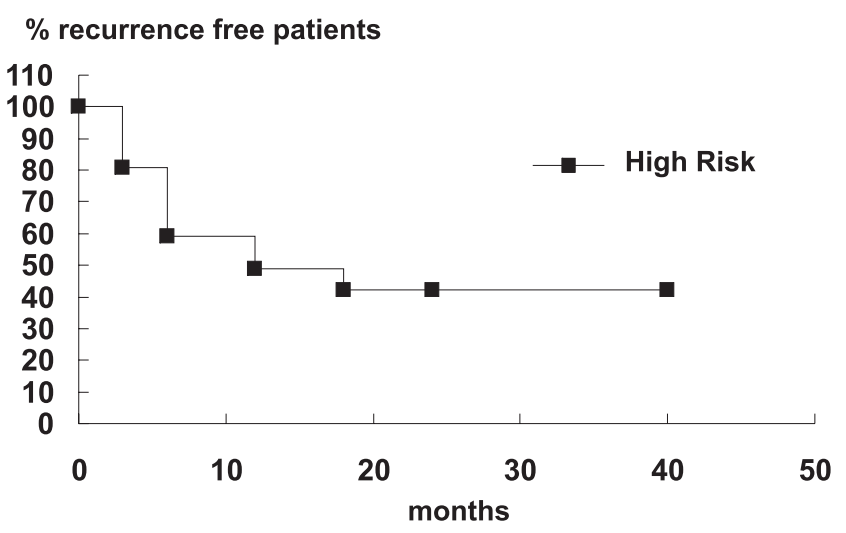

Figure 1 - Kaplan Mayer curve showing recurrence based on PSA for 21 high-risk prostate cancer patients

Radical prostatectomy was not performed in 14 patients due to severe comorbidities: 4 patients with previous acute myocardial infarction, 1 patient with cardiac arrhythmia, and 8 patients with severe diabetes mellitus.

Of the $13(57 \%)$ of patients for which the cryoablation procedure failed, only $6(47 \%)$ had biopsy-proven local recurrence with negative bone scan; 3 of these were treated with a reapplication of cryoablation. The other 3 patients, having no evidence of local recurrence (negative prostate biopsy), were treated with hormonal blockade only (Figure 2).

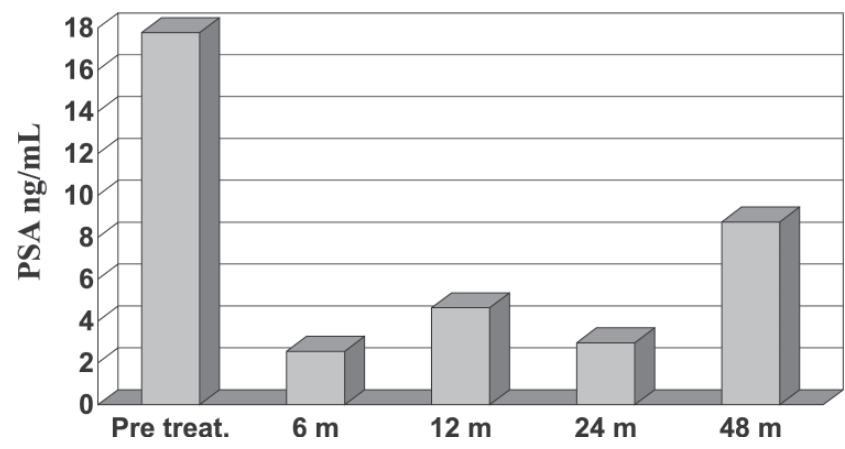

Figure 2 - PSA values in 21 high-risk prostate cancer patients after 6, 12, 24 , and 48 months of treatment with cryoablation

Complications were mostly minor, with $19 \%$ of mild hematuria and $13 \%$ of perineal/scrotum hematoma with no need for further treatment. There was no case of rectal injury, nor any need for blood transfusion. Urgency during the first 6 months of follow-up occurred in $23 \%$ of patients and was adequately managed with anticolinergic medications. Of the 14 previously potent patients, erectile dysfunction was found in 13 (93\%).

Urinary incontinence, defined as the need for 1 or more pads a day, was present in $12 \%$ of patients. One patient 
had a severe posterior urethral necrosis due to warming catheter malfunction during the freezing process. Urethral obstruction from prostate tissue sloughing occurred in 2 cases $(8 \%)$, which was treated by transurethral resection of the necrotic tissue.

\section{DISCUSSION}

In spite of the evolution of diagnostic methods, the prevalence of locally advanced or metastatic prostate cancer remains high, and some authors state that $20 \%$ of the prostate cancer cases are diagnosed with a high-risk presentation. The high-risk group of patients comprises a wide spectrum of disease, ranging from patients with aggressive localized disease to those with widespread occult distant metastases. Treatment of high-risk prostate cancer is still a challenge since the recurrence rate, regardless of the treatment modality, remains high. ${ }^{4,5}$

Multimodal treatment has been proposed for this subgroup, with assorted morbidities and oncologic results, such as radical prostatectomy associated with neoadjuvant hormone therapy or conformal radiotherapy associated with long-term hormone therapy. ${ }^{5,6}$

Prostate cryoablation, a minimally invasive treatment with low complication rates, has been proposed as a less invasive alternative treatment. ${ }^{7}$ However, when cryoablation is compared with radiotherapy, a noninvasive treatment, this advantage becomes less evident. Neverthless, high feasibility rates and the prompt return to regular life activities make cryoablation an attractive treatment.

Donnelly et $\mathrm{al}^{8}$ found $48 \%$ biochemical recurrence in high-risk patients treated exclusively by prostate cryoablation at the 5-year follow-up. Bahn et al, ${ }^{9}$ using a PSA-based definition of biochemical failure of $0.5 \mathrm{ng} / \mathrm{mL}$, found a recurrence-free rate of $39 \%$ at the 7 -year followup in high-risk patients. ${ }^{9}$

In a recent study, Prepelica et $\mathrm{al}^{10}$ performed cryoablation as the primary therapy for 65 high-risk prostate cancer patients (PSA over $10 \mathrm{ng} / \mathrm{dL}$ or Gleason 8 or higher) with a median follow-up of 35 months, finding durable PSA biochemical disease-free survival in about $83.3 \%$ of the patients according to the American Society for Therapeutic Radiology and Oncology (ASTRO) criteria.

In this study, we obtained a $61 \%$ and $47 \%$ biochemi- cal-free survival rate at 12 and 24 months of follow-up, respectively, for patients treated exclusively with prostate cryoablation. At the 5-year follow up, $43 \%$ of the patients were free of recurrence.

Stokes et $\mathrm{al}^{11}$ compared the long-term biochemical disease-free survival for patients undergoing radical prostatectomy, transperineal ultrasound-guided iodine-125 implantation, or external beam irradiation alone; the study was performed in patients stratified based on PSA, Gleason score, and staging. At 12 months of follow-up, only $40 \%$ of the patients undergoing external beam radiation and $51 \%$ undergoing seed implantation achieved PSA nadir $<1 \mathrm{ng} /$ $\mathrm{mL}$. In a multi-institutional review by Fiveash et al ${ }^{12}$ of 180 patients with high-grade prostate cancer treated with $3 \mathrm{D}$ conformal radiotherapy, the 5-year PSA recurrence-free survival was $62.5 \%$. This result was similar to the results of Bahn et $\mathrm{al}^{9}$ for high-risk patients.

Sylvester et $\mathrm{al}^{13}$ have been studying the effect of external beam radiotherapy in addition to brachytherapy, with $45 \%$ biochemical control at 10 years of followup, which is similar to the radical prostatectomy results but with shorter hospital stays and less morbidity.

Onik et al, treating unconfined prostate cancer, found $80 \%$ negative biopsies 6 months after cryoablation. ${ }^{14}$ In a study from the University of California at San Francisco, Shinohara et $a{ }^{15}$ treated 102 patients, with 61 patients having locally advanced disease (T3 and T4), and no technical problems were found. Real-time ultrasound control of freezing and monitoring techniques allowed a safe cryoablation, even with extra-prostatic freezing.

The results from those studies show that the ideal treatment for high-risk prostate cancer is still controversial, and new modalities and technologies must be developed in order to offer a better treatment with reduced morbidity for this group of patients.

\section{CONCLUSION}

Prostate cryoablation is a minimally invasive treatment with promising results, and perhaps if associated with hormonal therapy, resulting in low morbidity rates. It is a safe procedure even for high-risk patients, with low complication rates. The oncologic results are still poor for this group of patients, and new modalities of treatment must be sought.

\section{RESUMO}

Hayek ORE, Alfer Jr. W, Reggio E, Pompeo ACL, Arap S, Srougi M. Crioablação percutânea da próstata no tratamento do câncer de próstata de alto risco. Clinics. 2007;62(2):109-12. 
OBJETIVO: Avaliar a crioterapia percutânea como tratamento primário para o câncer de próstata de alto risco. PACIENTES E MÉTODOS: De outubro de 2000 a fevereiro de 2005, 21 pacientes com câncer de próstata de alto risco foram submetidos a 24 crioablações de próstata como tratamento primário. A mediana de idade dos pacientes foi de 70,9 , e a média do PSA pré-tratamento de $19,5 \mathrm{ng} / \mathrm{dl}$. O tempo de seguimento variou de 6 a 60 meses (mediana de 41 meses).

RESULTADOS: Os índices de falha do PSA foram de 39\% e 52,9\% respectivamente aos 12 e 24 meses de seguimento. A sobrevida livre de doença em 5 anos foi de $42,8 \%$. De maneira geral os índices de complicações foram baixos, com $8 \%$ de incontinência urinária e nenhum caso de lesão retal. Os índices de impotência foram de $96 \%$. Em doze pacientes $(57,2 \%)$ onde houve falha da crioablação, 7 $(58,3 \%)$ apresentaram recidivas locais (biópsia positiva) e os demais recidiva a distância.

CONCLUSÃO: A crioablação percutânea da próstata é um tratamento minimamente invasivo da próstata, seguro, porém ainda com resultados modestos em pacientes com câncer de próstata de alto risco, quando se considera a sobrevida livre de doença em 5 anos, havendo portanto necessidade de associação de outras modalidades terapêuticas no tratamento deste grupo específico de doentes.

UNITERMOS: Câncer de próstata. Crioterapia. Tratamento do câncer de próstata.

\section{REFERENCES}

1. Gonder MJ, Soanes WA, Shulman S. Cryosurgical treatment of the prostate. Invest Urol. 1966;3:372-8.

2. Soanes WA, Gonder MJ. Use of cryosurgery in prostatic cancer. J Urol. 1968;99:793-7.

3. Onik GM, Cohen JK, Reyes GD, Rubinsky B, Chang Z, Baust J. Transrectal ultrasound-guided percutaneous radical cryosurgical ablation of the prostate. Cancer. 1993;72:1291-9.

4. Skala M, Rosewall T, Warde P. Radiation therapy for high-risk prostate cancer-a review. Can J Urol. 2005;12 Suppl 2:28-32.

5. Ward JF, Slezak JM, Blute ML, Bergstralh EJ, Zincke H. Radical prostatectomy for clinically advanced (cT3) prostate cancer since the advent of prostate-specific antigen testing: 15-year outcome. BJU Int. 2005;95:751-6.

6. Bolla M, Maingon P, Fourneret P, Artignan X, Descotes JL. [Indications of the association of radiotherapy and hormonal treatment in prostate cancer]. Cancer Radiother. 2005;9:394-8.

7. Long JP, Bahn D, Lee F, Shinohara K, Chinn DO, Macaluso JN, Jr. Five-year retrospective, multi-institutional pooled analysis of cancerrelated outcomes after cryosurgical ablation of the prostate. Urology. 2001;57:518-23.

8. Donnelly BJ, Saliken JC, Ernst DS, Ali-Ridha N, Brasher PM, Robinson JW, et al. Prospective trial of cryosurgical ablation of the prostate: fiveyear results. Urology. 2002;60:645-9.
9. Bahn DK, Lee F, Badalament R, Kumar A, Greski J, Chernick M Targeted cryoablation of the prostate: 7-year outcomes in the primary treatment of prostate cancer. Urology. 2002;60(2 Suppl 1):3-11.

10. Prepelica KL, Okeke Z, Murphy A, Katz AE. Cryosurgical ablation of the prostate: high risk patient outcomes. Cancer. 2005;103:1625-30.

11. Stokes SH. Comparison of biochemical disease-free survival of patients with localized carcinoma of the prostate undergoing radical prostatectomy, transperineal ultrasound-guided radioactive seed implantation, or definitive external beam irradiation. Int J Radiat Oncol Biol Phys. 2000;47:129-36.

12. Fiveash JB, Hanks G, Roach M, Wang S, Vigneault E, McLaughlin PW, et al. 3D conformal radiation therapy (3DCRT) for high grade prostate cancer: a multi-institutional review. Int J Radiat Oncol Biol Phys. 2000;47:335-42.

13. Sylvester JE, Blasko JC, Grimm PD, Meier R, Malmgren JA. Ten-year biochemical relapse-free survival after external beam radiation and brachytherapy for localized prostate cancer: the Seattle experience. Int J Radiat Oncol Biol Phys. 2003;57:944-52.

14. Onik GM, Cohen JK, Reyes GD, Rubinsky B, Chang Z, Baust J. Transrectal ultrasound-guided percutaneous radical cryosurgical ablation of the prostate. Cancer. 1993;72:1291-9.

15. Shinohara K, Connolly JA, Presti JC, Jr., Carroll PR. Cryosurgical treatment of localized prostate cancer (stages $\mathrm{T} 1$ to $\mathrm{T} 4$ ): preliminary results. J Urol. 1996;156:115-20; discussion 120-1. 